\title{
Should urinary biomarkers be a standard component of evaluation after cardiac surgery?
}

\author{
Daniel T. Engelman, MD, FACS, a,b and John A. Kellum, MD, FACP, MCCM
}

\footnotetext{
From the a Department of Surgery, Baystate Medical Center, Springfield, Mass; ${ }^{b}$ University of Massachusetts Medical School-Baystate, Springfield, Mass; and ${ }^{\mathrm{c}}$ Department of Critical Care Medicine, University of Pittsburgh, School of Medicine, Pittsburgh, Pa.

Disclosures: D.T.E. is a speaker for Mallinckrodt Pharmaceutical, a consultant for Astute Medical, and is on the Medical Advisory Board for Pavilion Medical. J.A.K. reports grant support and consulting fees from Astute Medical and Bioporto.

Received for publication Dec 28, 2017; accepted for publication Dec 28, 2017; available ahead of print Feb 1, 2018.

Address for reprints: Daniel T. Engelman, MD, FACS, 759 Chestnut St, Springfield, MA 01199 (E-mail: Daniel. Engelman@baystatehealth.org).

J Thorac Cardiovasc Surg 2018;155:2453-4

$0022-5223 / \$ 36.00$

Copyright (C) 2018 by The American Association for Thoracic Surgery

https://doi.org/10.1016/j.jtcvs.2017.12.095
}

After cardiac surgery, acute kidney injury (AKI) develops in $15 \%$ to $30 \%$ of patients. ${ }^{1}$ The development of AKI after cardiac surgery is associated with significant morbidity and mortality, ${ }^{2,3}$ prolonged intensive care unit and in-hospital stays, ${ }^{4}$ increased treatment costs, and decreased long-term survival and quality of life. Standard risk-assessment tools have been ineffective in reducing this incidence.

In this important study by Albert and colleagues, ${ }^{5}$ a variety of kidney injury biomarkers including neutrophil gelatinase-associated lipocalin (NGAL), interleukin-6, midkine, and total protein were measured and correlated with survival after cardiac surgery in 200 patients at a single center. Patients with chronic renal impairment were excluded. Biomarkers were obtained preoperatively and at 6 and 24 hours after cardiopulmonary bypass. Kidney function was assessed at 90 days and 5 years after discharge. AKI was defined according to the R-risk, I-injury, or F-failure (RIFLE) criteria using serum creatinine and urinary output, both assessed during the first 7 postoperative days. ${ }^{6}$

The majority of patients (67\%) had no AKI (RIFLE -). RIFLE + patients were older and had longer, more complicated procedures and more blood transfusions. The most interesting finding, however, was that, independent of RIFLE status, urinary biomarker-positive patients had worse outcomes. NGAL +/RIFLE - patients had a 10-fold increased in-hospital mortality compared with NGAL -/RIFLE - patients. Similar, although less profound, findings were noted for the other biomarkers, midkine, and interleukin-6.

Subclinical AKI or kidney stress is a relatively new concept. ${ }^{7}$ It is characterized by a positive biomarker without subsequent creatinine or urine output-based criteria for AKI. Whereas stress may not lead to damage, particularly if the stress is eliminated promptly, ${ }^{8,9}$ subclinical AKI implies damage below the clinical detection threshold but

\section{References}

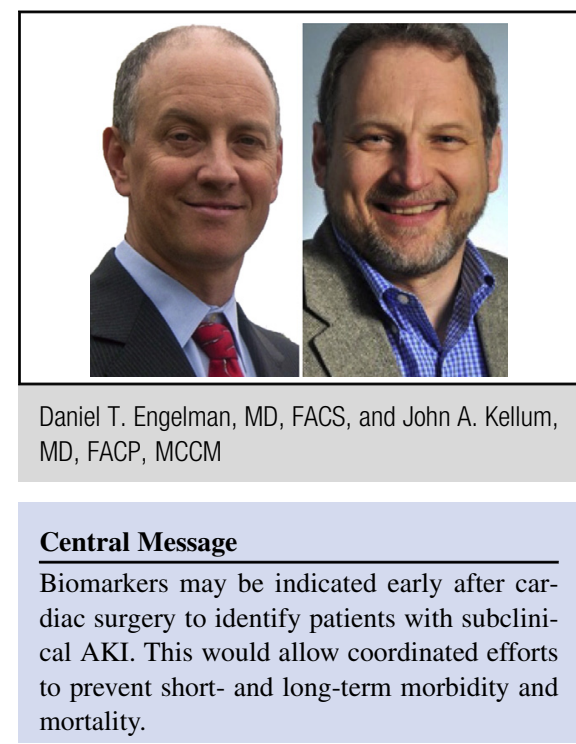

See Article page 2441.

revealed as decreased survival when biomarkers are positive. By using different urinary biomarkers, clinicians have successfully reduced the incidence of postcardiac surgery AKI by $30 \%$ with directed implementation of care bundles based on the Kidney Disease Improving Global Outcomes AKI guideline in biomarker-positive patients. These bundles include hemodynamic monitoring and titration, avoidance of nephrotoxic agents, higher transfusion thresholds, discontinuation of angiotensinconverting enzymes and angiotensin receptor blockers, and nephrology consultation. ${ }^{9,10}$ In the future, standard postoperative care will certainly include the use of these early indicators (within several hours after cardiac surgery) to deploy a multidisciplinary rapid response effort $^{11,12}$ to eliminate kidney stress and prevent subclinical and clinical AKI.

1. Kramer RS, Herron CR, Groom RC, Brown JR. Acute kidney injury subsequent to cardiac surgery. J Extra Corpor Technol. 2015;47:16-28.

2. Luckraz H, Gravenor MB, George R, Taylor S, Williams A, Ashraf S, et al. Long and short-term outcomes in patients requiring continuous renal replacemen therapy post cardiopulmonary bypass. Eur J Cardiothorac Surg. 2005;27:906-9.

3. Howell NJ, Keogh BE, Bonser RS, Graham TR, Mascaro J, Rooney SJ, et al. Mild renal dysfunction predicts in-hospital mortality and post-discharge survival following cardiac surgery. Eur J Cardiothorac Surg. 2008;34:390-5.

4. Nandi J, Mishra PK, Luckraz H, Nevill AM, Denyer S, Kitchlu R, et al. Short and long term outcomes (including quality of life) in patients with postoperative Acute Kidney Injury (AKI) after cardiac surgery. Interact Cardiovasc Thorac Surg. 2014;19(suppl 1):S18-19. 
5. Albert C, Albert A, Kube J, Bellomo R, Wettersten N, Kuppe H, et al Urinary biomarkers may provide prognostic information for subclinical acute kidney injury after cardiac surgery. J Thorac Cardiovasc Surg. 2018;155: 2441-52.e13.

6. Bellomo R, Ronco C, Kellum JA, Mehta RL, Palevsky P. Acute renal failure - definition, outcome measures, animal models, fluid therapy and information technology needs: the Second International Consensus Conference of the Acute Dialysis Quality Initiative (ADQI) Group. Crit Care. 2004;8:R204-12.

7. Katz N, Ronco C. Acute kidney stress-a useful term based on evolution in the understanding of acute kidney injury. Crit Care. 2016;20:23.

8. Göcze I, Jauch D, Götz M, Kennedy P, Jung B, Zeman F, et al. Biomarker-guided intervention to prevent acute kidney injury after major surgery: the prospective randomized BigpAK study. Ann Surg. August 29, 2017 [Epub ahead of print].
9. Meersch M, Schmidt C, Hoffmeier A, Van Aken H, Wempe C, Gerss J, et al. Prevention of cardiac surgery-associated AKI by implementing the KDIGO guidelines in high risk patients identified by biomarkers: the PrevAKI randomized controlled trial. Intensive Care Med. 2017;43: 1551-61.

10. Magruder JT, Crawford TC, Harness HL, Grimm JC, Suarez-Pierre A, Wierschke C, et al. A pilot goal-directed perfusion initiative is associated with less acute kidney injury after cardiac surgery. J Thorac Cardiovasc Surg. 2017; 153:118-25.e1.

11. Koyner JL, Garg AX, Coca SG, Sint K, Thiessen-Philbrook H, Patel UD, et al. Biomarkers predict progression of acute kidney injury after cardiac surgery. J Am Soc Nephrol. 2012;23:905-14.

12. Cruz DN, Ronco C, Katz N. Neutrophil gelatinase-associated lipocalin: a promising biomarker for detecting cardiac surgery-associated acute kidney injury. J Thorac Cardiovasc Surg. 2010;139:1101-6. 